\title{
Cognitive Mapping of the Noun Domains When Zero-deriving Proper from Common Nouns in Macedonian
}

\author{
Marjana Vaneva* \\ School of Foreign Languages, University American College Skopje, Treta makedonska brigada 60, 1000 Skopje, R. Macedonia
}

Received 27 Nov 2017, Accepted 10 Dec 2017, Available online 01 Jan 2018, Vol.6 (Jan/Feb 2018 issue)

\begin{abstract}
In zero-derivation, from element that belongs to a certain lexical (sub)category, by adding a zero-derivational affix, and with allowed inflectional modifications, a new lexeme is created, with absolutely the same form; similar, expanded meaning; but belonging to a different (sub)part of speech. Thus, the zero-derivational affix ensures the same (derivational) form of the new lexeme; with its own function, position, and distribution in the sentence, therefore representing a different word (sub)class; while the similar, connected, expanded meaning is achieved by cognitive mapping of the two lexemes' domains. In Macedonian, this very productive process of zero-derivation from common to proper noun is conducted by cognitively mapping the different subcategory domains of the noun class, by using metaphor and association links to semantically connect the lexemes and thus zero-derive a proper noun from a common one. E.g. ruža common $n . \rightarrow$ Ruža proper n. portrays the process when, by knowing the characteristics of the common noun - a pretty, nice-smelling flower, the hearer is expected to understand the similarity with the proper noun - the person named as Ruža will be/is as pretty and pleasant as the flower. This paper analyses the cognitive approach when zero-deriving Macedonian proper nouns from common ones.
\end{abstract}

Keywords: Cognition, Zero-derivation, Proper Nouns, Common Nouns, Macedonian.

\section{Introduction}

Zero derivation is, as can be inferred from its name, a derivational process in which by adding a zero (null) derivational affix to a lexeme, from one lexical category or subcategory, a new lexeme is being formed, which belongs to a different category or subcategory and therefore has a different distribution and position in the sentence, thus, performs another function; has a similar meaning to the first lexeme; and absolutely the same (derivational) form like the first lexeme; while inflectional modifications and interventions are allowed in favour of the process. This process exists in all languages, because semantic expansion happens freely and is a result of creativity on the part of the participants in conversation. Yet, it undoubtedly becomes even more common if and when analysed from a cognitive point of view.

Namely, generally speaking, cognition refers to the person's ability to comprehend and perceive the world around us, that is, to learning the new things on the basis of the old, already learnt facts, or understanding the new information by connecting it with the old, already acquired experience.

As far as the way of analyzing the meaning of lexical elements is concerned, the traditional model consists of

*Corresponding author's ORCID ID: 0000-0001-5641-4059 DOI: https://doi.org/10.14741/ijmcr.v6i01.10901 extracting and identifying the meanings of the same lexical element, in which way all meanings of the given lexeme are given the same status. Thus, what is done is that the lexemes are listed and zero derivation is observed from the lexemes' formal aspect without making a more detailed analysis of the meaning of lexemes and finding out connection between the source and the target word. Contrary to them, when analyzing the lexical meaning, the structural linguists try to find a common element which will unite all meanings that one lexeme has. However, this is not necessary at all; what is more, it can be even wrong considering the fact that the zero derived element does not carry in itself the semantic domain that the element has had in the source word class. Therefore, due to the need for a different and more systematic study of the language notions, cognitive linguistics has been recently developed as a separate part of the language study. The proponents of this theory claim that the systematic analysis of meaning should be based on the person's cognitive ability, that is, on the ability to perceive the world around us.

According to Saeed (1997: 299), the linguistic knowledge is part of the general cognition. The cognitive linguists emphasise the difference between the formal and the functional approach to the language. The first, to which the generative grammar belongs, is often

$8 \mid$ Int. J. of Multidisciplinary and Current research, Vol.6 (Jan/Feb 2018) 
connected with the understanding that knowledge of linguistic structures and rules forms an autonomous module, independent of the other mental processes for attention, memory and thinking. In that aspect, the study of linguistic semantics blurs the difference between the language knowledge and the encyclopedic knowledge from real life. As far as the second - functional - approach is concerned, which is maintained by the cognitive linguists, differentiating linguistic levels of analysis harms our language perceptions, since never can syntax be independent of semantics and pragmatics.

In the cognitive-linguistic literature, the meaning is based on the conventional concept structures. In this way, the semantic structure is formed to show the mental categories which people create on the basis of their behaviour and world experience. The cognitive linguists agree with the suggestion that Lakoff and Johnson (1980) make - that metaphor is the basic element in our categorization of the world as well as in the reflective processes. Thus, in cognitive linguistics, the metaphor is considered to be a basic instrument for the word's semantic expansion, that is, it maps the meaning of one lexical element from one domain onto another, when the meanings that superficially do not seem to be able to be connected, but the speaker regards as close and possible to be connected, are practically connected indeed.

Flavell, Miller and Miller (2002: 5-26) think that cognition embraces two parallel and complementary aspects which are called assimilation and accommodation. The first refers to adapting the stimulations from outside to our own inner mental structures, while accommodation is an opposite or complementary process - a process of adapting the mental to the outer stimulations structures. This system does not only make a mental copy of what has been experienced, but with assimilation the outer data is being interpreted and constructed with regards to the person's existing cognitive system; whereas with accommodation, the cognitive system is minimally changed to explain the outer data structure. In this continuous trial to adapt and assimilate the new, previously unassimilated elements from the surroundings, cognitive development occurs.

Nonetheless, cognitive linguistics, as a separate branch of linguistics, has its own, special approach to language, and the language development is based on one's power to perceive, while the people perceive by finding similarities of the new elements with the respective prototype of the given category. This shows that the inner structure of the word meaning is not autonomous and unique but it depends on our general stand on the world, whereas the word meaning is analysed on the basis of similarity with the prototype; more precisely, with the natural class of the lexeme.

When it comes to the prototype, it is the most prominent member of one category, and, Rosch (1977) by researching psychology, classifies the new notions in terms of their similarity with such an element. Namely, the more the notion resembles the prototype, the bigger the prospects are for it to be listed in a certain category. This means the role of the prototype is of immense importance in the cognitive study of the meanings of one lexeme because all semantic variants of one lexeme are connected with the prototype through closer or farther links by using metaphor, while the language users understand the abstract concepts by using physical experience. Hence, the principles of cognitive semantics are: to determine the prototype of one lexical category, and to make similarities and connections between the prototype and the other meanings of the lexeme, as well as to understand the role of the metaphor as an instrument for semantic expansion.

In the Macedonian literature there is no author who explicitly talks about zero derivation, but there are studies which treat the conversion of the lexeme from one lexical category or subcategory to another when using no overt affix, that is, by using a zero derivational affix. This proves that the process does exist in Macedonian (although named differently), but it is not studied enough or not paid sufficient scientific attention. What is even more, and worth noting here, is that it is definitely not seen through the prism of cognitive research.

Therefore, by using the knowledge of the process of zero derivation in English and by transferring the research findings of that language structure to Macedonian, the paper analyses a subtype of this phenomenon, that is, how proper nouns are zero derived from common nouns in Macedonian, by making cognitive transfer from one domain to another, thus expanding the semantics of the source lexeme.

\section{Materials and Methods}

This subtype of the process analyses the cases when the common noun is used as a source lexeme, from which the speaker takes the hearer to another lexeme, which, as a result of the process, is a proper noun. The transfer from one domain - common noun, to another - proper noun is made by semantically expanding the source lexeme, by using metaphor and by making association links between the existing and the resultant lexeme, that is, by finding similarities between the lexeme on the left and the person who should be named on the right. Thus, by applying the cognitive approach and by connecting the old, known lexeme on the left, the speaker names the person on the right; in which way they zero derive a proper noun. The new, proper noun embodies the semantic expansion of the old, common noun. Cognition is present here in the conceptual understanding of the similarities between the referents of both nouns used in the process. The corpus for this paper consists of lexemes that have been taken from Macedonian grammar books, dictionaries, or have been heard in everyday conversation but also noted in literary/poetic expression, while the sentence context has been structured either by the author or it has been taken from sources cited after the examples.

9 | Int. J. of Multidisciplinary and Current research, Vol.6 (Jan/Feb 2018) 
This type of zero deriving proper from common nouns will be analysed through three types:

2.1 The first type is represented by zero derived proper nouns, which name people:

роза $\rightarrow$ Роза: Има една роза во дворот. $\rightarrow$ Hашата нова сосетка се вика Роза.

[roza $\rightarrow$ Roza: Ima edna roza vo dvorot. $\rightarrow$ Našata nova sosetka se vika Roza.

rose $\rightarrow$ Rose: There is one rose in the yard. $\rightarrow$ Our new neighbor is called Rose.]

Here, the meaning, that is to say, the semantic implication is being transferred from common noun to a person's name when it refers to the fact that the person is named after the object or the plant that already exists. Thus, for example, the person called Roza gets its name after the flower roza, when with this process of zero derivation similarity in beauty between the flower and the girl is imposed. Therefore, as the rose is beautiful, so is the person who is given this name and contains the same characteristic on which the semantic closeness is based. Such lexemes are the following ones:

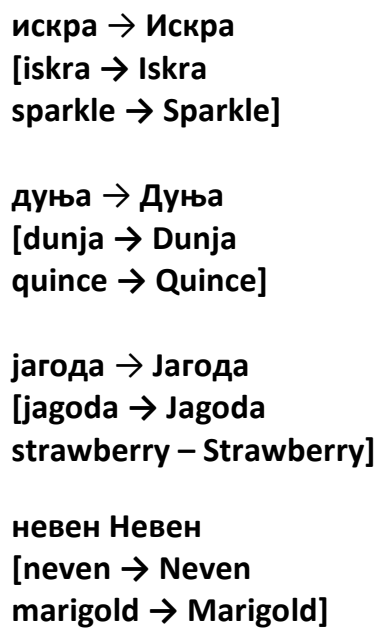

That this is a kind of zero derivation which is productive in the poetic expression and, in future, will be much more present in the language taking into account the formal and grammar limitations, and which occurs with a simple metaphoric transfer of meaning based on the cognitive abilities of the participants in the conversation, is being shown with the examples in continuation:

немир $\rightarrow$ Немир: Не можам да се ослободам од овој немир. $\rightarrow$ Крстеник да ми беше, со Немир би те крстел ...

[nemir $\rightarrow$ Nemir: Ne mozam da se oslobodam od ovoj nemir. $\rightarrow$ Krstenik da mi beše, so Nemir bi me krstel ... anxiety $\rightarrow$ Anxiety: I can't get rid of this anxiety. $\rightarrow$ If I were your godfather, I would name you Anxiety.]

M.M. p. 22

загуба $\rightarrow$ Загуба: Несреќата предизвика голема загуба. $\rightarrow$... на замин Загубо зборни ми: сакан мој самик. [zaguba $\rightarrow$ Zaguba: Nesreḱata predizvika golema zaguba. $\rightarrow$... na zamin Zagubo zborni mi: sakan moj samik, loss $\rightarrow$ Loss: The accident caused great loss. $\rightarrow$... on leaving, Loss say to me: my beloved, alone one, ...]

I. p. 38

These two examples are taken from the excerpted works Makedonski monolog (1969) and Izgrev (1989) respectively, both written by the Macedonian poet Gane Todorovski. This poet's poetry collections have been chosen because his poetic expression does not accept an absolute system of forms, but he is rather playful with words and that is exactly what creates new individua forms which can be used out of the poetic text itself. This kind of creativity being developed in poetry is then transferred in everyday life, where all newly formed words can be freely used.

However, in these two examples, what is noticeable is the motive to transfer the semantic similarity from the common to the proper noun when naming the person, and, in that way, the speaker shows their creativity to form proper names, through zero derivation, on the basis of metaphoric transfer and identical morphology. If the common noun nemir means absence of peace and calmness, the semantic expansion enables the speaker to be creative when naming the person as such that causes anxiety, discomfort, and absence of peace. Due to this, the person is given this name. The mutual semantic implication connects the two end domains: the condition when there is absence of peace and the person who causes such condition.

2.2 The second type is represented with proper names that name places, which are zero derived from common noun lexemes:

извор $\rightarrow$ Извор: Tие често одат на изворот Paшче. $\rightarrow$ Тој потекнува од селото Извор.

[izvor $\rightarrow$ Izvor: Tie često odat na izvorot Rašče. $\rightarrow$ Toj poteknuva od seloto Izvor.

spring $\rightarrow$ Spring: They often go to the Rašče spring. $\rightarrow$ His origin is from the Spring village.]

The same similarity between the common and the proper noun is present here, too, as are the same motives from which the place or the location receive their name. Namely, in the case with the lexeme izvor, which as a common noun means a place from where something comes or originates, by making metaphoric transfer, that is, by denoting a location from where something springs, the village in Veles, Izvor, has been named.

The following lexemes also belong to this group:

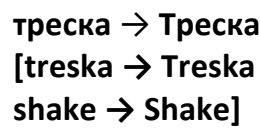

10 | Int. J. of Multidisciplinary and Current research, Vol.6 (Jan/Feb 2018) 


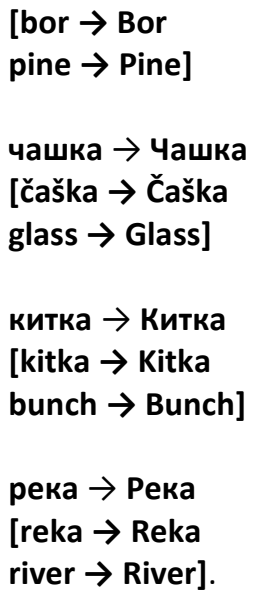

2.3. The third group consists of zero derivatives that are names of newspapers, magazines and other products that are of similar kind and deserve the same attention. The example given below will show the distribution of this sort of basic, source; and target, zero derived elements:

вест $\rightarrow$ Вест: убава вест $\rightarrow$ Утрово купив Вест.

[vest $\rightarrow$ Vest: ubava vest $\rightarrow$ Utrovo kupiv Vest.

news $\rightarrow$ News: good news $\rightarrow$ This morning I bought News.]

Here, the common noun vest that means information, news, zero derives a proper noun, which is a name of a newspaper, since the newspaper, as a medium, offers news and information. In this case, we ought to praise the creativity of the newspaper founders who have thought about the close link between what the newspaper offers and the name of this daily newspaper. This happens on the basis of the experience and the knowledge that the speaker has and uses them when making the transfer from the source to the target lexeme. Examples that belong to this kind of zero derivation are the following:

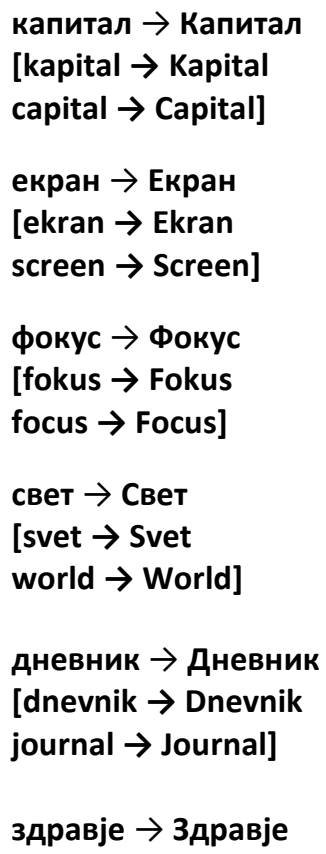

\section{[zdravje $\rightarrow$ Zdravje \\ health $\rightarrow$ Health]}

This subtype of zero derivation creates names of people, products, objects, newspapers, plants, but also of geographic concepts such as rivers, mountains, cities and countries. It seems that this group can go on to an infinite number of examples due to the process of zero derivation itself, which is developing fast and continuously increasing its productivity; moreover, because of the ability of the words of both types to be not only formally identical but also to show mutual semantic closeness.

In future, many new proper nouns could be created in this way, especially because there are no rules to be followed when naming something. Simply, if the new object, person or place, resembles the common noun in any way, then a zero derived proper noun would be easily formed, thus being a product of the process of zero derivation. And, once created, all these zero derived proper nouns behave in accordance with the requirements of the new group - that is, they do not accept suffixes for definiteness and plural; while due to the necessary formal identity between both lexemes, they maintain the same case belonging as the source common noun. Certainly, here the marginal case is mirrored in the different first letter which starts the source - the common noun, and that is a small letter, while the zero derived - proper noun, as the language rules require, is written with a first capital letter. This is how this process, the transfer and the semantic expansion can be schematically presented:

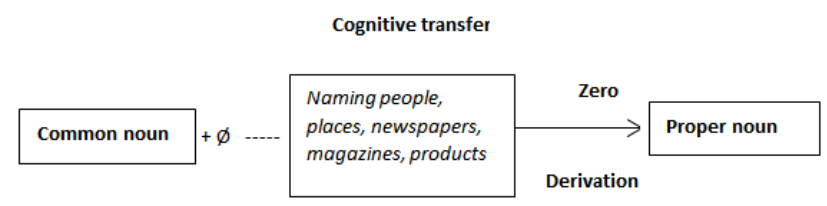

${ }^{1}$ Figure 1 Zero derivation from common to proper noun

\section{Results and discussion}

The result of the research shows that zero derivation from common to proper noun in Macedonian is a very easy and productive process when a new lexeme - proper noun - is created on the basis of the old lexeme - the common noun. In this way, by using metaphoric transfer and by making association links between the word whose meaning we know and the new notion that needs to be named, the naming of that notion is easily done. Actually, the new, zero derived element that gives a proper name to an entity is produced when a similarity is found between the meaning of the common noun and the new referent that needs to be named. When making the

${ }^{1}$ In the figure about this process, $\varnothing$ stands for a zero derivational suffix when by adding it to a common noun and by applying cognitive transfer, the characteristics listed before the process, in the scheme, portray the new lexeme - a proper noun created after the process takes place, that is, after zero derivation is conducted.

11 | Int. J. of Multidisciplinary and Current research, Vol.6 (Jan/Feb 2018) 
naming - the speaker, and when understanding it - the hearer, rely on the cognitive approach and the association links between the two lexemes in question. The easiness with which this process is realized makes it very productive in Macedonian, while as for the characteristics that mark it, it is marginal because the only (formal) difference between the two lexemes is in the first letter, that is, the zero derived, proper noun is written with a capital first letter, and full, because the new lexeme fully accepts the characteristics of the word subgroup whose member it is/becomes, so that its linguistics behaviour fits the new subpart of speech.

\section{Conclusions}

As could be concluded from the research done for this study and the discussion presented so far - that the process of zero derivation from common to proper noun, like the whole process of zero derivation, is a very productive mechanism for creating new words with which the vocabulary combination opportunities are increased and this is a process especially characteristic of analytical languages, while far less present in Slavic languages, the following is worth noting: namely, the vocabulary fond changes, is filled in and extends in several ways, and one of these is forming new words on the basis of the 'alive', productive models. Of course, language creators are all people who use it. It can be that one word does not exist in the language at a certain moment, but it will appear in a person's speech as a result of a spontaneous or conscious creative act by using a productive word formation model. This means it is potentially contained in the model. It can be incidental, accidentally emerged and, when the speech ends, that word will end too, but it can also be successful when, by being repeated by several speakers, it will take its own place in the language. Certainly, the participants in the conversation do not know all the words, and, when they form new lexemes, they use cognition, intuition and the previous experience, so that on the basis of the model, when lacking a word that they need, they create a lexeme which will better express their thought. In that way, they achieve two goals: be verbal and form words. This is exactly what is being done with the process of zero derivation and, more specifically, with this subtype of the process, from common to proper noun, because the noun category domain is mapped: we transfer the semantics of the first, common noun to the notion (person, place, newspaper, magazine) that we want to name and form a proper noun. Nevertheless, what aids this transfer of meaning between the lexemes and this easy understanding of the newly formed, zero derived proper noun is made possible with the cognitive approach and its essence to connect the meaning of the second lexeme due to knowing the semantics of the first element. We see that this process does exist in Macedonian and is likely to be more present and productive due to the need for faster, (technologically) more advanced communication, and speaker's more creative expression.

\section{References}

[1] Adams, V. (1973). Introduction to Modern English Wordformation, London: Longman.

[2] Arnold, I.V. (1986). The English Word. Москва: Высшая школа.

[3] Baker, M.C. (2003). Lexical Categories: Verbs, Nouns, and Adjectives. Cambridge: Cambridge University Press.

[4] Bauer, L. (1983). English Word-Formation. Cambridge: Cambridge University Press.

[5] Bauer, L. (1988). Introducing Linguistic Morphology. Edinburgh: Edinburgh University Press.

[6] Bauer, L., Valera, S. (2005). Approaches to Conversion/ZeroDerivation. Münster: Waxmann Publishing Co.

[7] Bugarski, R. (1991). Uvod u opšu lingvistiku: drugo izdanje. Beograd: Zavod za udžbenike i nastavna sredstva, Novi Sad: Zavod za izdavanje udžbenika.

[8] Chomsky, N. (1975). Reflections on Language. New York: Pantheon Books.

[9] Croft, W., Cruse, D.A. (2004). Cognitive Linguistics. Cambridge: Cambridge University Press.

[10] Cruse, A. (2000). Meaning in Language: An Introduction to Semantics and Pragmatics. Oxford: Oxford University Press.

[11] Flavell, J.H., Miller, P.H., \& Miller, S.A. (2002). Cognitive Development. $4^{\text {th }}$ edition. Prentice Hall.

[12] Huddleston, R., \& Pullum, G.K. (2005). A Student's Introduction to English Grammar. Cambridge: Cambridge University Press.

[13] Hudson, R. (1995). Word Meaning. London and New York: Routledge.

[14] Hurford, J.R., \& Heasley, B. (1983). Semantics: a coursebook. Cambridge: Cambridge University Press.

[15] Hurford, J.R. (1994). Grammar. A student's guide. Cambridge: Cambridge University Press.

[16] Jackson, H., \& Amvela, Z.E. (2000). Words, Meaning and Vocabulary: An Introduction to Modern English Lexicology. London and New York: Cassell.

[17] Katamba, F. (1993). Modern Linguistics. Morphology. London: Macmillan.

[18] Katamba, F. (1994). English Words. London and New York: Routledge.

[19] Koneski, B. (1967). Gramatika na makedonskiot literaturen jazik: del I i II. Skopje: Kultura.

[20] Koneski, K. (1995). Zboroobrazuvanjeto vo sovremeniot makedonski jazik. Skopje: Bona.

[21] Korubin, B. (1972). Za množinskite formi na imenkite vo makedonskiot jazik. Literaturen zbor, godina XIX, kniga 2, pp. 18 , Skopje.

[22] Kreidler, C.W. (1998). Introducing English Semantics. London and New York: Routledge.

[23] Langacker, R.W. (1967/1968). Language and Its Structure: Some Fundamental Linguistic Concepts. New York: Harcourt, Brace \& World, Inc.

[24] Leech, G. (1974). Semantics: The Study of Meaning. London: Penguin Group.

[25] Liles, L.B. (1975). An Introduction to Linguistics. New Jersey: Prentice-Hall, Inc.

[26] Ljung, M. (1994). English denominal adjectives. In Bright W. (ed.), Language Journal of the Linguistic Society of America. vol. 49, no. 3, pp. 704-714, Baltimore: Waverly Press Inc.

[27] Lyons, J. (1968). Introduction to Theoretical Linguistics. Cambridge: Cambridge University Press.

[28] Lyons, J. (1981). Language and Linguistics: An Introduction. Cambridge: Cambridge University Press.

12 | Int. J. of Multidisciplinary and Current research, Vol.6 (Jan/Feb 2018) 
[29] Lyons, J. (1995). Linguistic Semantics: An Introduction. Cambridge: Cambridge University Press.

[30] Marchand, H. (1969). The Categories and Types of Presentday English Word formation. $2^{\text {nd }}$ edition. Munich: Beck.

[31] Markov, B. (1997). Sostojbata i problemite na zboroobrazuvanjeto na makedonskiot jazik. In Pedeset godini na makedonskata nauka za jazikot: Prilozi od naučniot sobir održan od 30 noemvri do 2 dekemvri 1995 godina vo Skopje, pp. 117

125, Skopje: Makedonska akademija na naukite i umetnostite.

[32] McMahon, M.S.A. (1994). Understanding language change. Cambridge: Cambridge University Press.

[33] Minova-Ǵurkova, L. (1994). Sintaksa na makedonskiot standarden jazik. Skopje: Rading.

[34] Panoska, R. (1994). Sovremen makedonski jazik. Skopje.

[35] Plag, I. (2003). Word-Formation in English. Cambridge: Cambridge University Press.

[36] Gigova, M., \& Dimitrovski, T. (1983, 1987, 1993, 2001). Rečnik na makedonskata narodna poezija. tom: I, II, III, IV; Skopje: Institut za makedonski jazik "Krste Misirkov".

[37] Koneski, B. (1994) (ed.). Rečnik na makedonskiot jazik so srpskohrvatski tolkuvanja. tom: I, II, III, Skopje: Detska radost. [38] Sampson, G. (1980). Making Sense. Oxford: Oxford University Press.
[39] Saeed, J.I. (1997). Semantics. Oxford: Blackwell Publishers Ltd.

[40] Sazdov, S. (2004). Semantičkoto zboroobrazuvanje vo makedonskiot standarden jazik. (Doktorska disertacija), Skopje: Univerzitet "Sv. Kiril I Metodij", Filološki fakultet "Blaže Koneski".

[41] Sloat, C. (1969). Proper nouns in English. In Bright W. (ed.), Language Journal of the Linguistic Society of America, vol. 45, no. 1, pp. 26-30. Baltimore: Waverly Press Inc.

[42] Stefanovski, Lj. (1986). Produktivnosta vo zboroobrazuvanjeto kako osnoven dinamički aspect na leksikata. XII Naučna diskusija (Ohrid, 12-15 avgust 1985 godina), pp. 9097. Univerzitet "Sv. Kiril i Metodij", Skopje: Meǵunaroden seminar za makedonski jazik, literatura i kultura.

[43] Taylor, R.J. (1989). Linguistic Categorization: Prototypes in Linguistic Theory. Oxford: Oxford University Press.

[44] Ungerer, F., \& Schmid, H.J. (2006). An Introduction to Cognitive Linguistics. $2^{\text {nd }}$ edition. London: Pearson Longman.

[45] Veleva, S. (2006). Tendencii vo zboroobrazuvanjeto vo makedonskiot jazik. Skopje. 